九州大学学術情報リポジトリ

Kyushu University Institutional Repository

\title{
Cloning and Nucleotide Sequence of $\gamma-$ Polyglutamate Production Stimulating Factor on Bacillus subtilis (natto) Plasmid, pUH1
}

Hara, Toshio

Microbial Genetics Division, Institute of Genetic Resources, Faculty of Agriculture, Kyushu University

Nagatomo, Shinichiro

Microbial Genetics Division, Institute of Genetic Resources, Faculty of Agriculture, Kyushu University

\section{Iwamoto, Nobuhide}

Microbial Genetics Division, Institute of Genetic Resources, Faculty of Agriculture, Kyushu University

\section{Tadokoro, Yuko}

Microbial Genetics Division, Institute of Genetic Resources, Faculty of Agriculture, Kyushu University

他

https://doi.org/10.5109/24066

出版情報: 九州大学大学院農学研究院紀要. 39 (1/2)，pp.43-51，1994-12. Kyushu University バージョン：

権利関係: 


\title{
Cloning and $\mathrm{N}$ ucleotide Sequence of $\boldsymbol{\gamma}$-Polyglutamate Production Stimulating Factor on Bacillus subtilis (natto) Plasmid, pUH1
}

\author{
Toshio $\mathrm{Hara}^{+}$, Shinichiro Nagatomo, Nobuhide Iwamoto, Yuko Tadokoro, \\ Shinji Kaneko, Masahito Orima and Seiya Ogata
}

\author{
Microbial Genetics Division, Institute of Genetic Resources, Faculty of Agriculture, \\ Kyushu University, Fukuoka 812, Japan \\ (Received July 29, 1994)
}

\begin{abstract}
The gene coding for $\gamma$-polyglutamate production stimulating factor $(p s f)$ from Bacillus subtilis (natto) plasmid pUH1 was cloned and sequenced in Bacillus subtilis host. The activity of $\mathrm{y}$-glutamyltranspeptidase $(\gamma$-GTP) in B. subtilis host, which was introduced the psf gene was relatively high level, while its activity in $E$. coli host could not be detected. The nucleotide sequence of psf gene was determined and an open reading frame encoding a polypeptide composed of 420 amino acid residues (Mr, 49, 356) was identified. The putative -35 and -10 sequences, TTCAAA and TATTAT, were observed as the consensus sequence for the promoter recognized by the $\sigma^{43}$ RNA polymerase of $B$. subtilis, and the ribosome binding site, whose sequence was AACGAG, was complementary to the binding sequence of B. subtilis 16SrRNA except for one base. The amino acid sequence of $p s f$ with the segment of putative protein $\mathrm{C} 403$ of staphylococcal plasmid pE194 indicates homology, whereas that with $E$. coli and mammalian $y$-GTPs does not show any similarity at all.
\end{abstract}

\section{INTRODUCTION}

"Natto" is a Japanese traditional fermented food, manufactured by growing Bacillus subtilis (natto) on steamed soybeans. It is an adhesive, and consists of polysaccharide (levan-form fructan) and y-polyglutamate $(\boldsymbol{\gamma}$-PGA). The adhesive material is mainly composed of $\gamma$-PGA containing D-and L-glutamate in varying proportions (Fujii, 1963). A plausible mechanism of the biosynthetic pathway of $\gamma$ -PGA has been proposed by Thorne et al. (1955) for one of the $\gamma$-PGA-producing strains ( $B$. licheniformis ATCC9945A). However, since it is known that various strains differ a great deal in the basic requirements for $\gamma$-PGA synthesis as a capsule, it is to be assumed that there is more than one biosynthetic pathway. We reported that a $5.8-\mathrm{kb}$ plasmid designated pUH1, which is responsible for y-PGA synthesis, is distributed widely in $B$. subtilis (natto) strains isolated from a non-salty fermented soybean food, natto (Hara et al., 1983 ; 1993 ; unpublished results).

y-Glutamyltranspeptidase ( $\gamma$-GTP, EC2.3.2.2) catalyzes the transfer of the $\gamma$ -glutamyl residue from y-glutamyl compounds, such as glutathione, to amino acids and peptides, and the hydrolysis of y-glutamyl compounds (Tate and Meister, 1981), but its physiological role still remains controversial. The cDNAs of rat renal (Laperche et al., 1986) and human hepatic (Sakamuro et al.,1988) $\gamma$-GTPs were cloned, and the nucleotide sequences were determined. Recently, Suzuki et al. (1989) reported the

+ To whom all correspondence should be addressed. 
nucleotide sequence of Escheyichia coli $K-12$ y-GTP. However, the homology percent of amino acid sequence between the $E$. coli and mammalian $\gamma$-GTPs was quite low.

We have succeeded in expressing $\gamma$-GTP activity in $B$. subtilis host strains, which were introduced a $\gamma$-PGA production stimulating factor ( $p s f)$ gene. The $p s f$ gene might be responsible for $\gamma$-PGA synthesis in B. subtilis (natto). In the present work, we have sequenced the $p s f$ gene and compared with the $E$. coli and mammalian $\gamma$ - GTPs.

\section{MATERIALS AND METHODS}

\section{Bacterial strains and plasmids}

Escheyichia coli JM1Ol (supE44, thi, $\Delta($ lac-proAB) [F', proAB, lacIqZ $\Delta \mathrm{M} 15$, traD36], mcr $^{+}$) and Bacillus subtilis MI112 (ayg-15, leuB8, thy-5, recE4) were used as hosts for cloning and nucleotide sequencing. Plasmid pUH1 has been previously described (Hara et al., 1983). Plasmid pUB110 was used as a vector for B. subtilis host, and plasmids pATE1 (Hara et al., 1991) was for $E$. coli.

\section{Media}

LB broth and Panassary broth (Difco) for both $B$. subtilis and E. coli, Spizizen minimal medium for $B$. subtilis, and M9 minimal medium for $E$. coli were the same as described previously (Hara et al., 1991). The cells carrying $\mathrm{Km}$ ' plasmids were grown in AA medium (Tanaka and Sakaguchi, 1978) containing kanamycin $(50 \mu \mathrm{g} / \mathrm{ml})$.

DNA manipulations

The plasmidpUH1 from $B$. subtilis (natto) strain Asahikawa and its derived plasmids from Km' transformants were prepared and purified as previously described (Hara et al., 1983) was digested with BstEII, and then the ends were filled in with Klenow fragment to generate blunt ends. The DNA fragments were ligated with Bam HI liker, inserted at the Bam HI site of pUB110 with T4 ligase and then added to B. subtilis MI112 protoplasts. Restriction enzymes, T4 DNA ligase and bacterial alkaline phosphatase were purchased from Takara Shuzo Co., Ltd. (Kyoto, Japan), and used as recommended by the manufacture. Degradation of DNA with exonuclease Ba131 (Takara Shuzo Co., Ltd.) followed by procedure of Legerski et al. (1978).

Transformation procedure

E. coli JM101 was transformed by the method of Morrison (1977), and B. subtilis MI112 was transformed by using protoplasted cells (Hara et al., 1991).

Assessment of y-glutamyltranspeptidase assay

After cultivation at time indicated in the medium described by Fujii(1963), cells were harvested, suspended in $0.9 \% \mathrm{NaCl}$, and disrupted with a sonic oscillator (Branson Sonifer 185). The sonicated cells were centrifuged and the supernatant solution was used as intracellular enzyme preparation. The extracellular enzyme activity was measured in the culture fluid removed the cells by centrifugation. $\gamma$-GTP activity was assayed as previously described (Aumayr et al., 1981). One unit of $\gamma$-GTP activity is defined as the amount of enzyme which liberates $1 \mu \mathrm{mol}$ of a-naphthylamine per min at $37^{\circ} \mathrm{C}$.

DNA sequencing

DNA fragments were subcloned into plasmids pUC18 and pUC19, and then, if need, 
the Bal31-deleted derivatives were obtained by the stepwise deletion method of McCutchan et al. (1984). DNA sequencing was carried out by means of the dideoxy chain termination method (Sanger et al., 1977) with Sequenase Version 2.0 DNA Sequencing Kit (United States Biochemical Corporation, Cleveland, Ohio). Nucleotide and amino acid sequences were analyzed by the Hitachi DNASIS system.

\section{Chemicals}

Restriction enzymes, T4 DNA ligase and bacterial alkaline phosphatase were purchased from Takara Shuzo Co., Ltd., and used as recommended by the manufacture. Degradation of DNA with exonuclease Ba131 (Takara Shuzo Co., Ltd.) followed by procedure of Legerski et al. (1978).

\section{RESULTS AND DISCUSSION}

Cloning of pof gene in B. subtilis

As reported previously (Hara et al., 1981), the $p s f$ gene is encoded on an endogenous plasmid, pUH1 from $B$. subtilis (natto). We constructed a set of derived plasmids using pUB110 as a vector, in which a series of pUH1 fragments were inserted. Figure 1 shows the subclones of $B$. subtilis (natto) plasmid pUHl and their expression of $p s f$ in $B$. subtilis MI112. The $p s f$ activity was detected in several $\mathrm{Km}$ ' transformants, which carried plasmid pPB1 (column BsL in Fig. 1) with molecular size of 8.2 $\mathrm{kb}$, including 3.7-kb BstEII fragment of pUHl. To define the boundaries of a functional unit of inserted DNA, a 3.7-kb BstEII fragment of pUH1 was digested with selected restriction endonucleases to obtain a set of overlapping DNA fragments. The plasmid DNA preparations containing each generated fragments were tested for the enzyme activity in $B$. subtilis. The deletion experiments revealed that a $1.7-\mathrm{kb}$

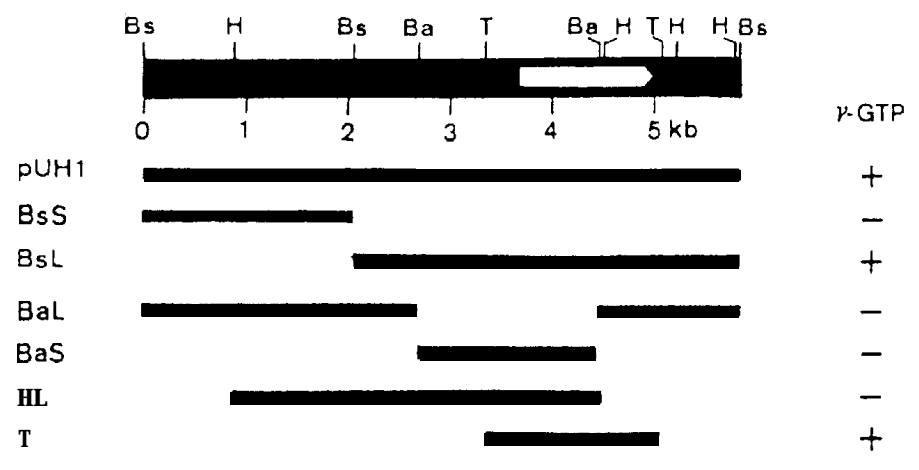

Fig. 1. Subclones of $B$. subtilis (natto) plasmid pUH1 and their expression of $\gamma$-GTP in $B$. subtilis $M 1112$.

The open arrow in the BstEII fragment indicates an open reading frame found in the sequence data (see Fig. 3). The activity of $\gamma$-GTP expressed was assayed as previously described (Aumayr et al., 1981). Abbreviations for restriction sites are : Ba, Bam HI; Bs, BstEII ; H, Hind111; T, TaqI. 
Table 1. $\gamma-\mathrm{GTP}$ activities in B. subtilis and E. coli strains carrying $p s f$ gene.

\begin{tabular}{llccc}
\hline & Strain & psf & \multicolumn{2}{c}{$\gamma$-GTP activity" } \\
\cline { 3 - 4 } & & & Intracellular & Extracellular \\
& & & & 41.8 \\
B. subtilis & Asahikawa & + & 10.1 & 423 \\
B. subtilis & MI112 & & 93.5 & 22.5 \\
& MI112 (pBS) & + & 8.3 & 91.5 \\
E. coli & JM1O1 & - & 8.0 & 10.6 \\
& JM1O1 (pHN-1) & + &
\end{tabular}

a Enzyme activities were measured under the conditions described in Materials and Methods.

TaqI fragment (column $\mathrm{T}$ in Fig. 1) is necessary for the expression of $p s f$ gene in $B$. subtilis MI112.

\section{Expression of psf gene in B. subtilis and E. coli}

The presence of $p s f$ gene on plasmidpUHl was confirmed by measuring the $\gamma$ -GTP activity in strains carrying the $p s f$. These results are summarized in Table 1, which includes the enzyme productivity of $B$. subtilis (natto) strain Asahikawa. The $B$. subtilis MI112 (pBS) carrying recombinant plasmidpBS expressed very high $\gamma$-GTP activity intracellularly at $93.5 \mathrm{mU} / \mathrm{ml}$ in the PY culture medium growth at $37^{\circ} \mathrm{C}$ for 24 hr, while the strain MI112 (pBS) accumulated extracellularly $\gamma$-GTP at level of 91.5 $\mathrm{mU} / \mathrm{ml}$ for 5 days. In order to compare the productivity of $\gamma-\mathrm{GTP}$ in E. coli with that in $B$. subtilis, we subcloned the 1.7-kb TaqI fragment of pUH1 into pATE1 constructed from pTL12 (Tanaka and Sakaguchi, 1982) (the recombinant plasmid obtained was designated pHN1). However, E.coli JMlOl carrying pHN1 did not express intracellularly the $\gamma$-GTP activity in LB broth grown at $30^{\circ} \mathrm{C}$ for $24 \mathrm{hr}$. Also, $\gamma$-GTP activity could not detect extracellularly after even 5-days cultivation.

\section{$\mathrm{N}$ ucleotide sequence of pUH1 psf gene}

Figure 2 shows the physical map and sequencing strategy of $1.7-\mathrm{kb}$ TaqI fragment including the $p s f$ gene of $B$. subtilis (natto) plasmid pUH1. The nucleotide sequences of both strands of the 1.7-kbTaqI fragment were determined by the dideoxynucleotide chaintermination method (Sanger et al., 1977) after successive Ba131 exonuclease deletions (Davis et al., 1986). The nucleotide sequence was determined for both strands by using numerous restriction fragments to give enough overlapping regions. Figure 3 shows the nucleotide sequence of the 1.7- $\mathrm{kbTaqI}$ fragment. By examination of possible open reading frames (ORFs), we found only one large frame, which consists of 1,260 bp and encodes a protein molecule with 420 amino acids and an $M \mathrm{r}$ of 49,356. The $p s f$ ORF was found to be preceded by a putative $\sigma^{43}$ RNA polymerase promoter of $B$. subtilis. The 5' upstream region of $p s f$ gene contains a 5'-AACGAG-3' sequence (indicated as SD in Fig. 3) complementary to the 3' end of 16SrRNA (3'-OH-UCUUUCCUCCAGUAG-5') of $B$. subtilis (McLaughlin et al., 1981) at nucleotides 295 to 300 for translation initiation. There is a 5'-TATTAT-3' sequence (-10 in Fig. 3) resembling a Pribnow box (Moran et al., 1982) at nucleotides 257 to 262, and at a site of $23 \mathrm{bp}$ upstream of this -10 sequence, there is a 5'-TTCAAA-3' sequence resembling the -35 sequence (Moran et al., 1982) of $B$. subtilis gene. The observed distance (17 bp) 


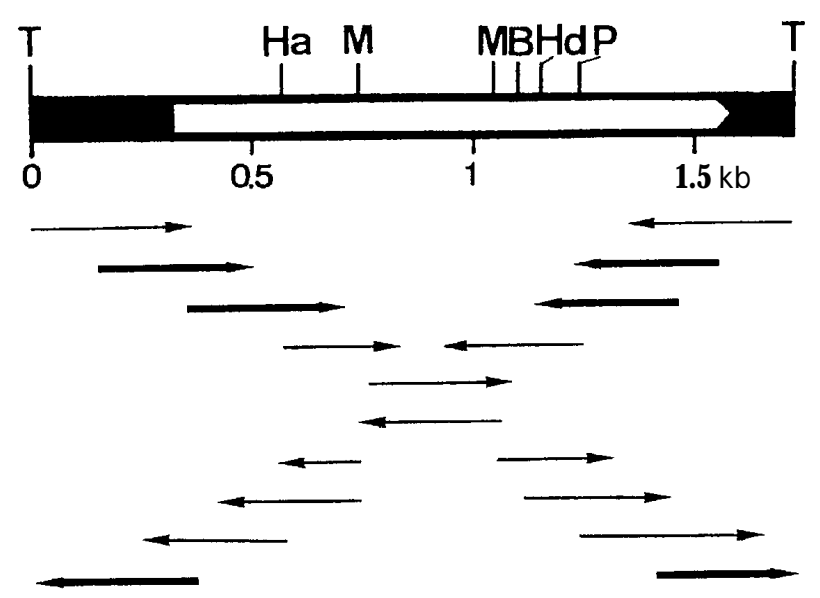

Fig. 2. Restriction map and sequencing strategy for the $p s f$ gene of B. subtilis (natto) plasmidpUH1.

The open arrow in the restriction map indicates an open reading frame found in the sequence data (see Fig. 3). Below the map, arrows indicate the direction and extent of sequencing either of subcloned restriction fragments (thin arrows) or of a series of deletion fragments prepared by Bal31 (thick arrows). Abbreviations for restriction sites are: B, Bam $\mathrm{HI} ; \mathrm{Ha}$, HaeIII ; Hd, HindIII ; M, MspI ; P, PvuII ; T, TaqI.

between the -10 and -35 sequences accords well with that observed generally in $B$. subtilis genes (17-18 bp) (Moran et al., 1982).

\section{Homology of PSF to other $\mathbf{y - G T P}$ genes}

The amino acid sequence of the predicted protein PSF encodes on pUH1 was compared with a number of protein sequences registered in GenBank with used of the homology search system of GENAS (Kuhara et al., 1984). As shown in Fig. 4, sequence homologous to the pUHl PSF were found to in putative protein C403 (420 residues ; Horinouchi and Weisblum, 1982) with 48,300 daltons encoded in staphylococcal plasmid pE194. Approximately, 51.2\% amino acid homologies with pUH1 PSF was observed in a segment of 86 residues of $\mathrm{C} 403$, but percent match of both proteins, in its entirety, was quite low value such as $11.9 \%$. The cDNAs of rat renal (Laperche et al., 1986) and human hepatic (Sakamuro et al. 1988), hepatoma (Goodspeed et al., 1989), and placental (Meyts et al., 1988) $\gamma$-GTPs were cloned, and the nucleotide sequences were determined. The mammalian $\gamma$-GTPs, whose amino acid sequences were essentially the same, are synthesized as single polypeptides and then processed into the large and small subunits (Matsuda and Katsunuma, 1984), but did not show any similarity at all with pUH1 PSF from $B$. subtilis (natto). Percent match of amino acid sequence of pUH1 PSF for human hepatic y-GTP was $8.4 \%$. Recently, Suzuki et al. (1989) performed DNA sequencing of E.coli y-GTP, and they suggested that the $E$. coli y-GTP might be also processed posttranslationally. The homology of amino acid 

GCCATGGCATAATTTGGTGTAGTGCGTTACACCAAAGATAAACTTTGTGTTACCATAACCCCTATACAGTG'́TCTGAATCGGGGTTTTT

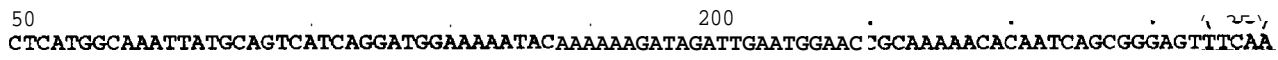

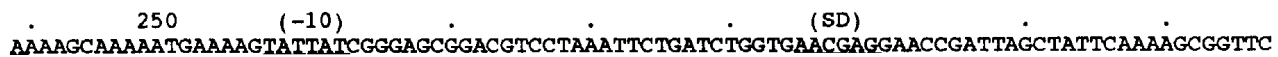
$350 \quad 400$ ATGAAAAAATTGAGGGTCGGGTCAAACGAAGGTCCGAGCGGATGCGTGTTTTGGTCAGCGAATTTTTGATCACGGCAAGTCCTGACTAT MetLysLySLeuArgValGlySerAsnGlyArgSerGluArgMetArgValLeuValserGluPheLeuIleThrAlaSerProAspTyr 450 500

ATGAAAGGGCTGAGTGATGAGGAGCAGCGGCGCTATTTTGAAACAGCGGTTGATCATTTGAAAGAGAAATACAGCGCTGAAAACATGCTT MetLysGlyLeuSerAspGlugluglnArgArgTyrPheGluThrAlaValAspHisLeuLysGluLysTyrSerAlaGluAsnMetLeu

TATGCCACAGTCCATATGGATGAAGCGACTCCCCATATGCATGTTGGTATTGTACCGATCACGGAGGACGGCCGACTCTCTGCGAAAGAT

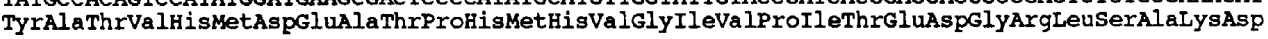
00

TTTTTTAATGGCAAATTGAAGATGAAAGCCATTCAAGATGATTTTCATCGGCACATGGTTGAAAACGGTTTTGACCTGGTGCGCGGCGAA PhePheAsnglyLysLeuLysMetLysAlaIleGlnAspAspPheHisArgHisMetValGluAsnglyPheAspLeuValArgGlyGlu 700 750

CCGAGCGAAAAGAAGCATGAGAATGTTCACCAGTATAAAATCAATCAGCGGCAAGCGGAGCTTGAGCGGCTTAATGCTGAAATTGCTTTA ProserGluLysLysHisGluAsnValHigGlnTyrLys IleAsnglnargGlnAlagluLeugluArgLeuAsnAlagluIleAlaLeu 800 850

AAGGAAAAGCAGAGAGAGGAACTGGAAAAGCAAAACAAAGCTGTTCAAGCAGTTATAGAAGTGAAAAAAGAATCACTGACAGCTAAGGCT LysGluLysGlnArgGlugluLeuGluLygGInAsnLysAlaVa GGInAlaValI legluvalLysLysGluSerLeuThrAlaLysAla 900 950

GAAGAGTTGAAAATGCCGACTATTGAACATGAAAAAGCGTGCCTCAAAAAGGATAAAGTCATTGTGCCGGAGCGGGAACTCCATGCTTTG GluGluLeuLysMetProThrIleGluHisGluLysAlaTrpLeuLysLysAspLysVali leValProGluArgGluLeuHisAlaLeu • $1000 \quad 10$ TACGCCTATGCGGAGCAGAAAACTAAAACGACAGCCGAGCTGGCGGGGCAATTGAAGTCAGAAACGCAGGAAAAGGAGCGCTGGCAGTCT TyrAlaTyrAlagluGInLys ThrLysThrSerAlaGluLeuAlaglyGlnLeuLysSerGluThrGlnGluLysGluArgTrpGlnSer $50 \quad 1100$

ATCGCCCGGCAGAAGCAGATCGGGCAGATGAAAAAGACCAACGGCTTCAGGAACTGCAGAGTAAGATCCATICAGAAGTTGAAGCGTCCA IleAlaArgGinLysGInI leGlyGlnMetLysLys ThrAsnGlyPheArgAsnCysArgValargSerIleGlnLysLeuLysArgPro 1150 1200

AAAAGGAAATGCGGCCAAGCTTGCAAAGGAATTTACGGAAGAGCAAGCGTGAGGATCTTCGGCAGGAAGTGAAAGAGGAGCTGACGGCT LySArgLysCysGlyAlaSerLeuGlnArgAsnLeuArgLysSerLysArgGluAspLeuArgGlnGluValLysGluGluLeuThrAla 1250 1300

TTACGAACGgAAATAAGAACTGCTAGCTGAAAATAAAGTCTTGATCATTGAGAGGAATCGTGAAGCTGAGGAAAACTTAAAACTAAAA LeuArgThrGluAsnLysGluLeuLeuAlagluAsnLysValLeuIleIlegluArgasnargGluAlaglugluAsnLeuLysLeuLys CAGGAACTTGATAAGAGAGACGGGCAGTATGCTGAGGTTTTGAGTTCGCCCAGAAGCAGAACCAAACACTTGAAAAAGTGGCTGGAGAA GlnGluLeuAspLysArgAspGlyGInTyrAlaGluValLeuSerPheAlaGlnLysGlnAsnglnThrLeuGluLysValAlaGlyGlu

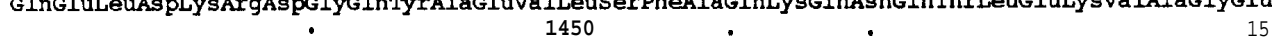
AACAAGGCATTAAAAAAAGAAAATAAGACACTAAAAGAGAGAGTTGCTGTATTAGAAGAGTGGAAAGATAAAATGGTGCAGTGGGCTAAA AsnLysAlaLeuLysLysluAsnLysThrLeuLysGluargVa lalavalLeuglugluTrpLysAspLysMetValglnTrpAlaLys 00

GAAAGGTTACCAAAGATGCGGAAATTAGCGGCATCGTTTTTCAATACAGCAGGTATCGTCGAGAAGCTGCTAAATATAAGGACAATGAAT GluArgLeuProLysMetArgLysLeuAlaAlaserPhePheAsnThrAlaGlyI leValgluLysLeuLeuAsnIleArgThrMetAsn $1600 \quad 1650$ TGGAGCGATAAATGGTTTCTTAAGCGGTGAAAACGGGCAAGTGAATTAGTCTTCCAAAATTGCCACCACTTTTTTTGTTTAGTGGCTGC TrpserAspLysTrpPheSer ** *

$$
1700 \text { TagI }
$$

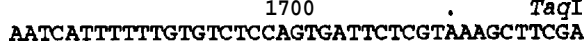

Fig. 3. Nucleotide sequence and the deduced amino acid sequence of psf gene of $B$. subtilis (natto) plasmid pUH1.

The putative $-35,-10$ and SD sequences were indicated by underlines and the possible terminator sequences are shown by arrows. Nucleotides are numbered from the 5' end of TaqI site of the 1.7-kb DNA strand with the same polarity as mRNA. Amino acid sequences are shown below the coding frame. 
10

20

30

40

50

1 s. aureus PE194 C403 MSHSILRVARVKGSSNTNGIQRHNQRKNKNYNNKDINHEETYKNYDLINA

2 PUH 1 PSF

3 PNKH PSF

4 E. coli $\mathrm{K}-12 \quad \gamma-\mathrm{GTP}$

5 Human hepatic $\gamma$-GTP

MIKPTFLRRVAIAALLSGSCF SAAAAPPAPPVSYGVEEDVFHPVRAKQ VKKKLWLGLLAVVLVLVIVGLCLWLPSASKHPDNHVYTR

60

80

90

100

110

120

QNIKYKDKIDETIDENYSGKRKIRSD-AIRHVDGLVTSDKDF FDDLSGEEIERFFKDSLEFIENEYGKEN MRKLRGESNGRSERMHVLVSEFLITASPDYMNGLSDEEORRYFETAVDHIKEKYSAEN MKKLRGESNGRSERMRVLVSEFLITASPDYMKGLSDEEQRRYEETAVDHLKEYYSAEN GMVASVDATATQVGVDILKEGGNAVDAAVAVGYAIAVTHPQAGNLGGGGFMLI-RSKNGNTTAIDFR-EM AAVAADAKOCSKIGRDALRDDDSAVDAAIAALLCVGLMNAHSMGTGGGLFLTIYNSTTRKAEVINAR-EV

130 140 150 160 170 180 190 MY-LAT---------VHLDERVPHMHFGFVPLTEDGRISAKEQLGNKKDFTQLQDRFN--EYVNEKGYE ML-YAT---------VHMDEATPHMHVGIVPITEDGRLSAKDFF NGKLKMKAIQDDFH--RHMVENGFD ML-YAT-- -----VHMDEATPHMHVGIVPITEDGRISAKDFF NGKLKMKAIQDDFH--RHMVENGFD APAKATRDMFLDDOGNPDSKKSLTSHIASGTPGTVAGFSLALDKYGTMPLNKVVQPAFKLARDGF IVNDA APRIAFATMF-NS-SE-QSQKG--G-LSVAVPGEIRGYELAHQRHGRLPWARLFQPSIQLARQGF FVGKG

200

210

220

230

240

250

260

LERGTSKEVT-EREHKAMDQYKKDTVFHKQELQEVKDELQKANKQLQSGIEHMRSTKPFDYENERTGLFS LVRGE PSEKKHENVHQYK-INQRE PEIERLNAE IALKEKQREELEKQNKAVQAVIEVKKE SLTAKAEELK IVRGE PSEKKHENVHOYK - INOROAEIERLNAE I ALKEKOREELEKONKAVOAVIEVKKESLTAKAEELK LADDLKTYGSEVLPNHENSKAIFWKEGEPLKKGDTLVQANLAKSLEMIAENGPDEFYKGT IAEQIAQEMQ LAAALEN-KRTVIEQQPVLCEVFCRDRKVLREGERLTLPQLADTYETLAIEGAQAFYNGSLTAQIVKDIQ

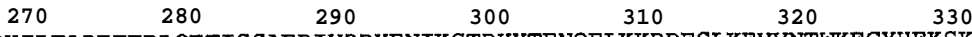

1 GREETGRKILTADEFERIQETISSAERIVDDYENIKSTDYYTENQELKKRRESLKEVVNTWKEGYHEKSK MPTIE HEKAWLKKDKVIVPERELHALYAYAEOKTKTAAELAGQ-LKSETQE-KERWQSIARQEADR-ADE MPTIE HEKAWLKKDKVIVPERELHALYAYAEQKTKTTAE LAGQ-LKSETQE-KERWQSIARQE ADR-ADE KNGGLITKE DLAAYKAV-ERTPISGDYGYQVYSMPPPSSGGI HIVQILNILENF DMKKYGFGSAD--AMAAGGIVTAEDLNNYRAELIE HPLNISLGDAVLY-MPSAPLSGPVLALILNILKGYNF SRESVE SPEQKGL

350

360

370

380

390

400

EVNKLKRENDSLNEQLNVSEKFQASTVTLYRAARANFPGFEKGFNRLKEKF FNDSKFERVGQFMDVVODN KDQRLQELQSRIHSEVEASKKEMRRKLAKEFD---T---EEQRQDLRQEVKEELTTLRTENEELSAENKV KDQRLQELQSKIHSEVE ASKKEMRRKLAKEFD---T---EEQREDLRQEVKEELTALRYENKELLAENKV -OIMAEAEKYAYADRSEYLGDPDFVKVP-W--WALTNKAYAKSIADOIDINKAKPSSEIRPGKLAPYESN TYHRIVEAFRFAYAKRT-LIGDPKFVDVTEVVRNMTSEFFAAQLRAQISDDTTHPISYYKPEFYTP-DDG $410 \quad 420$

430

440

450

460

470

VQKVDRKREKQRTDDLEM LI IERNRE AEENLKLKOELDKRDGOY AEVLSFAOKQNOTLEKVAGENKALKKENKTLKERVAVIEEWKDK QTTHYSVVDKDGNAVAVTYTLNITFGTGIVAGESGI LLNNQMDDF SAKPGVPNVYGLVGGDANAVGPNKR GTAHLSVVAEDGSAVASTSTINLYFGSKVRSPVSGI LFNNEMDDF SS-PSITNEFGVPPSPANF IQPGKQ

$\begin{array}{lllllll}480 & 490 & 500 & 510 & 520 & 530 & 540\end{array}$

2 MVQWAKFKLPKMRKLAASFFVRLECLEKP INTRTMN

MVOWAKEKLPKVRRLAVSFFNTAGIVEKLLNIRTMNWSDKWFS

PLSSMSPTIVV-KDGKTWLVTGSPGGSRI ITTVLQMVVNSIDYGLNVAEATNAPRFHHQWLFDELRVEKG PLSSMCPTIMVGQDGQVRMVVGAAGGTQITTATALA I IYNLWFGYDVKRAVEE PRLHNQLLFNVTTVERN

$\begin{array}{lllll}550 & 560 & 570 & 580 & 590\end{array}$

4 FSPDTLKLLEAKGQKVALKEA-MGSTQSIMVGPDGELYGASDPRSVDDLTAGY

5 IDQAVTAALETRHHHTQIASTF IAWQAIVRTAGG-WAAASDSRKGGE-PAGY

Fig. 4. Comparison of the amino acid sequences of the pUH1 and pNKHPSFs, the putative protein C403 of pE194 and the E. coli and human hepatic $\gamma$-GTPS.

The putative C403 encodes on staphylococcal plasmid pE194 is from Horinouchi and Weisblum (1982). The pNKH PSF is from Hara et al. (1994). The E. coli y-GTP is from Suzuki et al., (1989). The human hepatic y-GTP sequence is from Sakamuro et al., (1988). Gaps have been inserted to gain maximum matching. The one-letter amino acid code has been used. Percent match of amino acid sequence of pUH1 PSF for C403 on plasmid pE194 was $11.9 \%$, and for $E$. coli and human hepatic $\gamma$-GTPs were $7.8 \%$ and $8.4 \%$, respectively. 
sequences between the E.coli y-GTP and pUH1 PSF is relatively low, and percent match was only $7.8 \%$. Furthermore, the percent match of amino acid sequence among mammalian and E.coli $\gamma$-GTPs was not so high (ca. 30\%). Though mammalian $\gamma$ -GTPs are connected with metabolism of glutathione-related compounds, but the organisms cannot procedure $\gamma$-PGA, like B. subtilis (natto) strains. It is, therefore, to be assumed that there are more than one enzyme catalyzes the transfer of the $y$ -glutamyl residue from $\gamma$-glutamyl compounds, and that one of them plays a important role in y-PGA synthesis in B. subtilis (natto).

Recently, the B. subtilis y-GTP was cloned and sequenced by 'Katsumata et al. (1991). The sequence contains a single open reading frame encoding the signal peptide and large and small subunits, in that order, as is the case with E.coli y-GTP (Suzuki et al., 1989), but should be concerned with y-PGA production in B. subtilis (natto).

\section{REFERENCES}

Aumayr, A., T. Hara and S. Ueda 1981 Transformation of Bacillus subtilis in polyglutamate production by deoxyribonucleic acid from B. natto. J. Gen. Appl.Microbiol., 27: 115-123

Fujii, H. 1963 On the formation of mucilage by Bacillus natto. Part III. Chemical constituents of mucilage in natto. Nippon Nogeikagaku Kaishi, 37:407-411

Goodspeed, D. C., T. J. Dunn, C. D. Miller and H. C. Pitot 1989 Human $\gamma$-glutamyl transpeptidase cDNA : comparison of hepatoma and kidney mRNA in the human and rat. Gene, $76: 1-9$

Hara, T., A. Aumayr and S. Ueda 1981 Characterization of plasmid deoxyribonucleic acid in Bacillus natto: Evidence for plasmid-linked PGA production. J. Gen. Appl. Microbial., 29 : 299 $-305$

Hara, T., J. T. Lee, T. K. Prana, T. Akamatsu, Y. Fujio and S. Ogata 1991 Successive protoplast transformation of Bacillus subtilis by plasmid DNA under low concentration of lysozyme. J. Fac. Agr., Kyushu Univ., $36: 23-28$

Hara, T., S. Nagatomo, S. Ogata and S. Ueda 1991 Molecular structure of the replication origin of a Bacillus subtilis (natto)plasmid,pUH1.Appl. Environ. Microbiol., 57: 1838-1841

Hara, T., S. Ogata and S. Ueda 1993 Plasmid distribution in y-polyglutamate-producing Bacillus strains isolated from "dan-douchi", a "natto"-like non-salty fermented soybean food in China. $J$. Gen. Appl. Microbiol., $39: 75-82$

Hara, T., H. Saito, N. Iwamoto and S. Kaneko 1994 Plasmid analysis in $\gamma$-polyglutamate-producing Bacillus strains isolated from non-salty fermented soybean food, "kinema" in Nepal. J. Gen. Appl. Microbiol., in press.

Hara, T., J. R. Zhang and S. Ueda 1983 Identification of plasmids linked with polyglutamate production in Bacillus subtilis (natto). J. Gen. Appl.Microbiol., 29:345-354

Horinouchi, S. and B. Weisblum 1982 Nucleotide sequence and functional map of pE194, a plasmid that specifies inducible resistance to macrolide, lincosamide, and streptogramin type B antibiotics. J. Bacteriol., 150: 804-814

Katsumata, R., T. Minakami, K. Ohta, M. Satoh and K. Yamaguchi 1991 Japan Patent 3-232486

Kuhara, S., F. Matsuo, S. Futamura, A. Fujita, T. Shinohara, T. Takagi and Y. Sakaki 1984 GENAS : a database system for nucleic acid sequence analysis. Nucleic Acids Res., 12 : 89-99

Kyte, J. and R. F. Doolittle 1982 A simple method for displaying the hydropathic character of a protein. J. Mol. Biol., $157: 105-132$

Laperche, Y., F. Bulle, T. Aissani, M. N. Chobert, M. Aggerbeck, J. Hanoune and G. Guellaen 1986 Molecular cloning of rat kidney gamma-glutamyl transpeptidase cDNA.Proc. Natl. Acad. Sci., USA, $83: 937-941$

Legerski, R. J., J. L. Hodnett and H. B. Jr. Gray 1978 Extracellular nucleases of Pseudomonas Ba131. III. Use of the double-strand deoxyribonuclease activity as the basis of a convenient 
method for the mapping of fragments of DNA produced by cleavage with restriction enzymes. Nucleic Acids Res., 5 : 1445-1464

Matsuda, Y. and N. Katsunuma 1984 Biosynthesis and processing of $\gamma$-glutamyl transpeptidase. Seikagaku, $56: 1389-1403$

McCutchan, T. F., J. L. Hansen, J. B. Dame and J. A. Mullins 1984 Mung bean nuclease cleaves Plasmodium genomic DNA at sites before and after genes. Science, 225: 625-628

McLaughlin, J. R., C. L. Murray and J. C. Rabinowitz 1981 Unique features in the ribosome binding site sequence of the Gram-positive Staphylococcus aureus $\beta$-lactamase gene. J. Biol. Chem., 256 : 11283-11291

Meyts, E. R. D., N. Heisterkamp and J. Groffen 1988 Cloning and nucleotide sequence of human $\gamma$-glutamyl transpeptidase. Proc. Natl.Acad. Sci., USA, $85: 8840-8844$

Moran, C. P. Jr., N. Lang, S. F. J. LeGrice, G. Lee, M. Stephans, A. L. Sonenshein, J. Pero and R. Losick 1982 Nucleotide sequence that signal the initiation of transcription and translation in Bacillus subtilis. Mol. Gen. Genet., $202: 169-171$

Morrison D. A. (1977) Transformation in Escherichiacoli: cryogenic preservation of competent cells. J. Bacteriol., $132: 349-351$

Sakamuro, D., M. Yamazoe, Y. Matsuda, K. Kangawa, N. Taniguchi, H. Matsuo, H. Yoshikawa and N. Ogasawara 1988 The primary structure of human gamma-glutamyl transpeptidase. Gene, 73: $1-9$

Sanger, F., S. Nicklen and A. R. Coulson 1977 DNA sequencing with chainterminating inhibitors. Proc. Natl. Acad. Sci., USA, $74: 5463-5467$

Suzuki, H., H. Kumagai, T. Echigo and T. Tochikura 1989 DNA sequence of the Escherichiacoli K-12 y-glutamyltranspeptidase gene, ggt. J. Bacteriol, 171: 5169-5172

Tanaka, T. and K. Sakaguchi 1978 Construction of a recombinant of B. subtilis leucine genes and a B. subtilis (natto) plasmid : its use as cloning vehicle in B. subtilis. Mol. Gen. Genet., 165 : 269 $-276$

Tate, S. S. and A. Meister $1981 \gamma$-Glutamyl transpeptidase: catalytic structural and functional aspects. Mol. Cell. Biochem., 39: 357-368

Thorne, C. B., C. G. Gomez and R. D. Housewright 1955 Further studies on the biosynthesis of $\gamma$-glutamyl peptides by transfer reactions. J. Biol. Chem., 212: 427438 